\title{
Miranda
}

Revue pluridisciplinaire du monde anglophone /

Multidisciplinary peer-reviewed journal on the English-

speaking world

18 | 2019

Guerre en poésie, poésie en guerre

\section{Charlotte Gould, Artangel and Financing British Art: Adapting to Social and Economic Change}

\section{Hélène Ibata}

\section{OpenEdition}

\section{Journals}

\section{Electronic version}

URL: http://journals.openedition.org/miranda/17581

DOI: 10.4000/miranda. 17581

ISSN: 2108-6559

Publisher

Université Toulouse - Jean Jaurès

\section{Electronic reference}

Hélène Ibata, "Charlotte Gould, Artangel and Financing British Art: Adapting to Social and Economic

Change", Miranda [Online], 18 | 2019, Online since 16 April 2019, connection on 16 February 2021. URL: http://journals.openedition.org/miranda/17581 ; DOI: https://doi.org/10.4000/miranda.17581

This text was automatically generated on 16 February 2021.

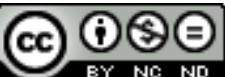

Miranda is licensed under a Creative Commons Attribution-NonCommercial-NoDerivatives 4.0 International License. 
Charlotte Gould, Artangel and Financing British Art: Adapting to Social and Economic Change

Hélène Ibata

\section{REFERENCES}

Charlotte Gould, Artangel and Financing British Art: Adapting to Social and Economic Change (New York and London: Routledge, 2018), 154 p, ISBN 978-1-138-48981-3 


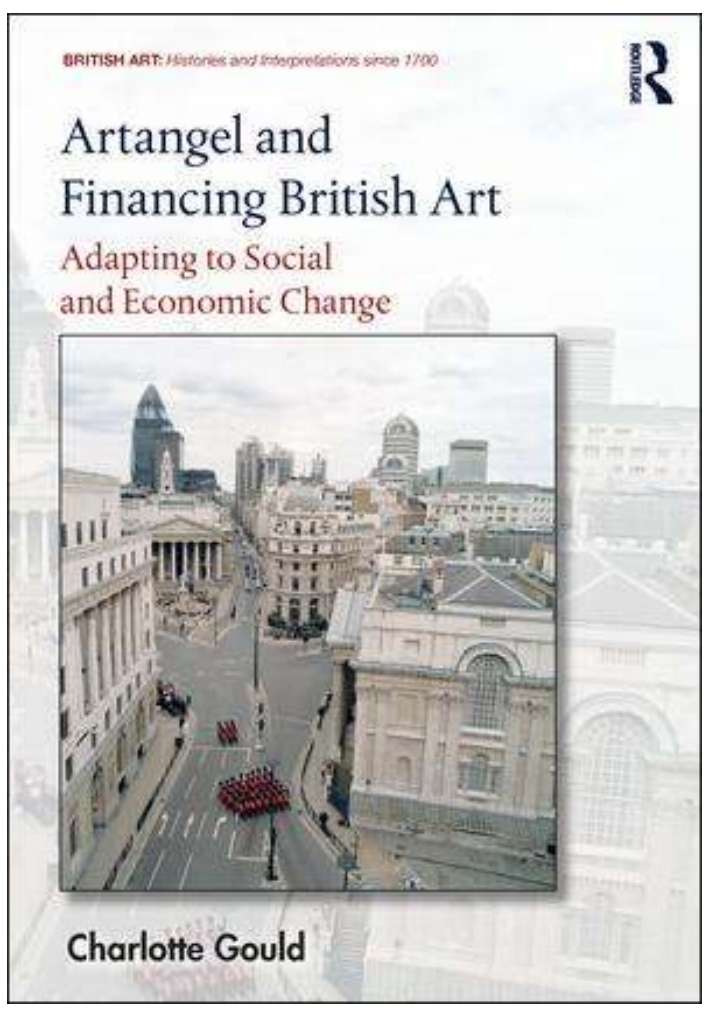

1 Since Iain Pears's The Discovery of Painting (1988) and David Solkin's Painting for Money (1993), art historians have demonstrated the fruitfulness of exploring British art through the lens of the art market, patronage and cultural policies. They have shown that the funding models of art, whether they involve institutions or patronage, or both, actually shape art practices as much as they respond to artists' creativity.

Charlotte Gould's book, which explores the contemporary social, economic and institutional contexts of art in Britain through the case study of Artangel, is a noteworthy addition to this relatively new branch of scholarship.

3 Artangel is an independent art commissioning agency, created in 1985, whose main activity has consisted in promoting and funding adventurous artistic creation in the context of a major paradigm shift in cultural production, and especially in response to the emergence of cultural capitalism and to the unreliability of public funding in postconsensus Britain. Its original approach combines a flexible hybridised funding model (with funds being provided by Arts Council England, private donors as well as corporate sponsors), active participation towards the completion of contemporary artistic projects rather than simple funding, and at the same time a conscious decision to give artists as much creative independence as possible in order to advance the cause of contemporary art. As Gould puts it, Artangel "allow artists to commission themselves". The agency's lasting success in the last thirty years is due to its adaptability to changing social, political and economic conditions, and above all to its ability to embrace the new terms of artistic creation. This includes its awareness of the central importance of the interaction of art and place in contemporary creation (it has actually become a leader in location finding), and its acceptance of the ephemeral in productions that are embedded in transient spatial and temporal contexts.

4 Gould's study of Artangel is a compelling exploration of the recent reshaping of the art world in an age when the distinctions between private and public patronage are 
becoming blurred and when the process of creation has become as important as the product, often leading to ephemeral, "pop-up", interventions, and productions in which the locus of creation is merged with that of exhibition.

The book highlights the intricate connection between artistic forms and funding models through a thorough exposition of the mechanisms and fluctuation of funding for art since the 1980s, and examines a wide range of responses to the shifting forms of state funding that have been experimented with since the first Thatcher government.

6 It also explores Artangel's contribution to the redefinition of the location of art in the post-museum age, at a time when the boundaries between public and private, aesthetic and commercial spaces are being redrawn. It raises important questions about the recent redefinitions of the public sphere, their contested nature, and the way they shape spectatorship and creation, without seeing these new conditions as necessarily a source of constraints on artistic expressions. It especially highlights Artangel's encouragement of site-specific creations that play a vital role in contemporary urban environments and cultural geographies, by reviving depressed areas, by retrieving hidden or underlying meanings that official urban planning decisions had suppressed, as well as by interacting with the fabric of everyday life and thereby fusing the processes of artistic creation with those of the city. At the same time, it does not hide the fact that these creative uses of urban spaces have an ambiguous status, especially when they contribute to gentrification processes or are instrumentalised by developers, and can be a source of social tensions, for example when works of art are inserted in poor neighbourhoods, as in the case of Roger Hiorn's 2010 Seizure (pp. 103-104) or planned in contested spaces (pp. 107-110).

7 There are many thought-provoking pages on Artangel's interactions with the recent reconfigurations of London, and its predilection for transitional and unstable spaces, often caught in the midst of redevelopment projects, that are in themselves a source of innovation and whose latent energy can be fused into the artwork. Numerous examples of creative uses of London's transitory fabric and in-between spaces are given, including Daniel Silver's 2013 Dig, a pretend archaeological site in near King's Cross, Richard Wentworth's An Area of Outstanding Unnatural Beauty (2002), a 10-week multiactivity programme around the same King's Cross area at a time when it was being redeveloped, or Roger Hiorn's Seizure.

8 Gould makes it obvious that Artangel is more than an illustration, but a lens through which the contemporary art world, its creative and productive mechanisms, its agents and institutional framework, as well as its discursive processes of production, may be understood. And as she examines how Artangel has navigated the ambiguities of the post-consensus context in Britain, which saw the disengagement of the state and various forms of cultural capitalism alternate with regenerative and socially committed cultural policies, while the boundaries between private and public spheres oscillated and evolved, she gives the reader a good idea of the bigger picture. The history of the agency provides a remarkable insight into the new spirit of artistic production, its new focus on project and process rather than product, on "a certain type of experience" and on the siting of works rather than the commodification of art.

Because of this new focus, the task of the art historian is as much to account for the processes of production, financing, location hunting, as it is to describe the product. Gould's study is a very convincing illustration of this new requirement, of the necessity to approach the production process differently, through all its facets, especially its 
interaction with specific locations and the meaningful contexts that these provide. Yet, occasionally, the reader may experience a desire to know more about the artworks themselves. The numerous artistic projects that are mentioned are very convincing illustrations of what Artangel stands for and of the numerous contexts, agencies and intentions at work in the creation of contemporary art, yet they may remain tantalisingly elusive to a reader who expects more concrete evocations. It is difficult not to read Gould's study without wanting to know more about the configurations, however transient, of some of the Inner City performances (1998-99), of Andy Goldsworthy's On Hampstead Heath (1985-86), of Ben Rivers' 2015 project The Two Eyes are not Brothers, or of the A Room for London project (p. 99), for example.

Perhaps, however, these artworks have to remain elusive, as their raison d'être is precisely the transient part they play in the life of the city, which can be experienced better than it can be captured. In which case Gould's book is a very persuasive evocation of the new artistic paradigm that Artangel represents, in the age of "postobject" art, in which the cultural importance of the artwork matters more than its actual presence. It also underscores the exclusive nature (and possible elitism) of projects that were in many cases only accessible to a restricted number of viewers, and may only be appreciated through virtual afterlives. The book's main value, however, lies in its ability to convey the thriving and innovative art scene of Britain, of London in particular, in the last three decades, and to highlight its connections with changing socio-economic conditions, ideological commitments and cultural policies. As such, it raises many compelling issues for anyone with an interest in contemporary art, British cultural policies, and also contemporary British society.

INDEX

Keywords: cultural policies, contemporary art, patronage, creative processes, site-specificity, London

Mots-clés: politiques culturelles, art contemporain, mécénat, processus créatifs, art in situ, Londres

\section{AUTHORS}

\section{HÉLÈNE IBATA}

Maître de conférences

Université de Strasbourg

hibata@unistra.fr 